\title{
Pollen morphology of Malpighiaceae from Brazilian forest fragments
}

\author{
Talita Kely Belonsi • Eduardo Custódio Gasparino
}

Received: 18 September 2014/ Accepted: 7 January 2015/Published online: 10 February 2015

(c) Botanical Society of Sao Paulo 2015

\begin{abstract}
The pollen morphology of 12 Brazilian native species of Malpighiaceae from forest fragments was investigated in search to expand the morphological knowledge of the species analyzed thus contributing to its palynology, taxonomy, and conservation. The pollen grains were acetolysed, measured, photographed using light microscopy and scanning electron microscopy, and described qualitatively. The quantitative data were analyzed by descriptive statistics and multivariate statistics. The pollen grains are monads, apolar or isopolar, small to large, with circular to quadrangular amb, oblate-spheroidal to prolatespheroidal, tricolporate with long colpi and lalongate endoaperture or 6-(7-8)-porate with or without colpoids and aspides, psilate-rugulate, rugulate or microreticulate exine, sexine thicker than nexine in most species. The results of this study point to differences in the morphology of the pollen grains in the analyzed species, which indicates Malpighiaceae as a eurypalynous family; this fact was also confirmed by quantitative data and the multivariate analysis. These data reinforce the importance of pollen morphology for identification and distinction of genus and species of the family.
\end{abstract}

Keywords Brazil · Eurypalynous · Palynotaxonomy · Pollen grains

\footnotetext{
T. K. Belonsi · E. C. Gasparino $(\bowtie)$

Departamento de Biologia aplicada à Agropecuária, Faculdade de Ciências Agrárias e Veterinárias de Jaboticabal (FCAV), Univ. Estadual Paulista, Unesp, Jaboticabal, SP 14.884-900, Brazil

e-mail: ecgasparino@fcav.unesp.br
}

\section{Introduction}

Malpighiaceae, an important family within the eudicots groups, is part of Malpighiales and has approximately 1,300 species in 77 genera (APG III 2009; Davis and Anderson 2010). They occur as trees, shrubs, and climbers that are widespread in tropical, subtropical forests, and savanna occurring in the Old and New World, its current distribution and diversification are probably a result of the breakdown of the Gondwana (Anderson 1990, 1993; Amorim 2002; Davis et al. 2002a). There are about 534 species in 44 genera of Malpighiaceae in Brazil, which are distributed in almost all states (Mamede et al. 2014).

Some Malpighiaceae species were identified as the main representatives of the remnant forest fragments in the northwest of São Paulo state, along with three other prominent families: Apocynaceae, Bignoniaceae, and Sapindaceae (Ranga et al. 2012). These areas initially formed by Atlantic Forest now consist of small forest fragments and large areas of Cerrado, mostly due to forest fragmentation process that usually leads to loss of biodiversity (Kronka et al. 1993; Turner 1996; Myers et al. 2000).

Malpighiaceae has a high morphological variety, especially regarding the types of habits, fruits, and also of pollen grains (Niendenzu 1928; Lobreau 1967, 1968), this probably has happened reflecting the extensive ecological and geographical distribution. An important feature of the family is the presence of unicellular hairs usually attached, so that the trichome has two arms (in T-, V- or Y-shaped), the stalk is often short and the arms straight to twisted (Niendenzu 1928; Robertson 1972; Rao and Sarma 1992). The types of fruits and trichomes are of great systematic importance to the family and also widely used in the characterization of genera (Anderson 1981; Judd et al. 2009) 
Recent papers on the molecular biology of Malpighiaceae pointed out new data on the traditional classification of the family, suggesting the importance of more detailed studies (Cameron et al. 2001; Davis et al. 2001, 2002a, b, 2004; Davis and Anderson 2010). The family is currently divided into two subfamilies, Byrsonimoideae W. R. Anderson, with New World genera and Malpighioideae Burnett, with species distributed in the New and Old World (APG III 2009). According to Anderson (2004), the New World Malpighiaceae genera have unicellular branched trichomes, simple and opposite leaves, bilateral flowers with two oil glands on the abaxial surface sepals, 10 stamens and a tricarpellate gynoecium with one ovule per locule. Some of these characteristics have been lost in the Old World genera (Anderson 2004; Davis and Anderson 2010)

The pollen morphology of Malpighiaceae has been described in the studies of Erdtman (1952), Lobreau (1967, 1968), Salgado-Labouriau (1973), Anderson (1982), Lobreau-Callen (1983), Makino (1986), Makino-Watanabe (1988), Roubik and Moreno (1991), Makino-Watanabe et al. (1993a, b, 1998), Amorim (2003), Melhem et al. (2003), Gonçalves-Esteves et al. (2007), Magalhães-e-Silva (2007), Sousa et al. (2010), Dutra et al. (2014), and Sebastiani et al. (2014). These studies report about the palynology of the family, its genera or isolated species, and the differences in the pollen grains analyzed indicate Malpighiaceae as eurypalynous.

Continuing the pollen morphology characterization for forest fragments areas (Souza and Gasparino 2014), the aim of this study is to contribute with morphological data, which will be used in future taxonomic or pollinic studies (such as geopalynology, melissopalynology, etc.) that include Malpighiaceae species and assisting so their conservation.

\section{Materials and methods}

We studied the pollen grains of 12 Malpighiaceae native species (Appendix) from the remnant forest fragments of the northwest area São Paulo state. Ranga et al. (2012) describes 14 Malpighiaceae species for the area, however Janusia intermedia (A.St.-Hill.) A. Juss. cited in this paper is currently from synonymy with Byrsonima intermedia A. Juss., and also Carolus chlorocarpus (A. Juss.) W. R. Anderson was not analyzed by lack of pollen material. The pollen materials were obtained from dried herbarium specimens supplied from JABU and SJRP herbaria, of samples taken mainly in the remnant forest fragments of northwest São Paulo State. Pollen grains of 24 specimens were studied by light microscopy (LM) and scanning electron microscopy (SEM), and the pollen grains of Diplopterys pubipetala, Mascagnia cordifolia, Peixotoa tomentosa, and Stigmaphyllon lalandianum had not been studied previously. The pollen grains were acetolysed according to the methods of Erdtman (1960) and Melhem et al. (2003) and measured, under LM, within seven days after their preparation (Salgado-Labouriau et al. 1965). For SEM analysis, pollen grains were prepared according to Melhem et al. (2003) to both acetolysed and non-acetolysed pollen grains. Permanent slides of light microscopy are deposited in the pollen reference collection of the Departamento de Biologia aplicada à Agropecuária, Universidade Estadual Paulista, Unesp, Jaboticabal, Brazil.

Pollen diameters $(n=25)$ and the other characteristics (of aperture and exine thickness, $n=10$ ) were measured in the pollen samples under LM. Statistical analysis was conducted to obtain the means (x), standard deviation (sx), standard error (s), $95 \%$ confidence intervals (CI), coefficient of variability $(V)$, and range $(R)$ following Vieira (1981) and Zar (1996). To compare the values of the pollen grain diameters, we used the diameter I and diameter II (for apolar pollen grains) and diameter in equatorial view (for isopolar pollen grains), and the data represented by graphs of MINITAB program. The mean was calculated for exine thickness, length and width of apertures. To verify whether the pollen data allowed the grouping of species, a principal component analysis (PCA) was performed using the programs FITOPAC (Shepherd 1996) and PC-ORD (McCune and Mefford 1999). For this analysis, we used 11 metric variables: length of colpus (CLEN), width of colpus (CWID), polar diameter in equatorial view or diameter I (DIAI), equatorial diameter in equatorial view or diameter II (DIAII), equatorial diameter in polar view (EDPV), length of endoaperture (ELEN), width of endoaperture (EWID), pore diameter (PDIA), exine (EXIN), nexine (NEXI), and sexine (SEXI).

Photomicrographs were performed with a light microscope Leica IM50 for LM photos, and with a JOEL, JSM5410 scanning electron microscope for the SEM images. Pollen description and terminology follows Barth and Melhem (1988) and Punt et al. (2007) glossaries, Faegri and Iversen (1966) and Gasparino et al. (2013) were adopted for the polar area index and for width index of colpi, respectively.

\section{Results}

General description

The pollen grains of the Malpighiaceae species studied here (Figs. 1-12, 13-24, 25-36, 37-46) are monads, apolar 


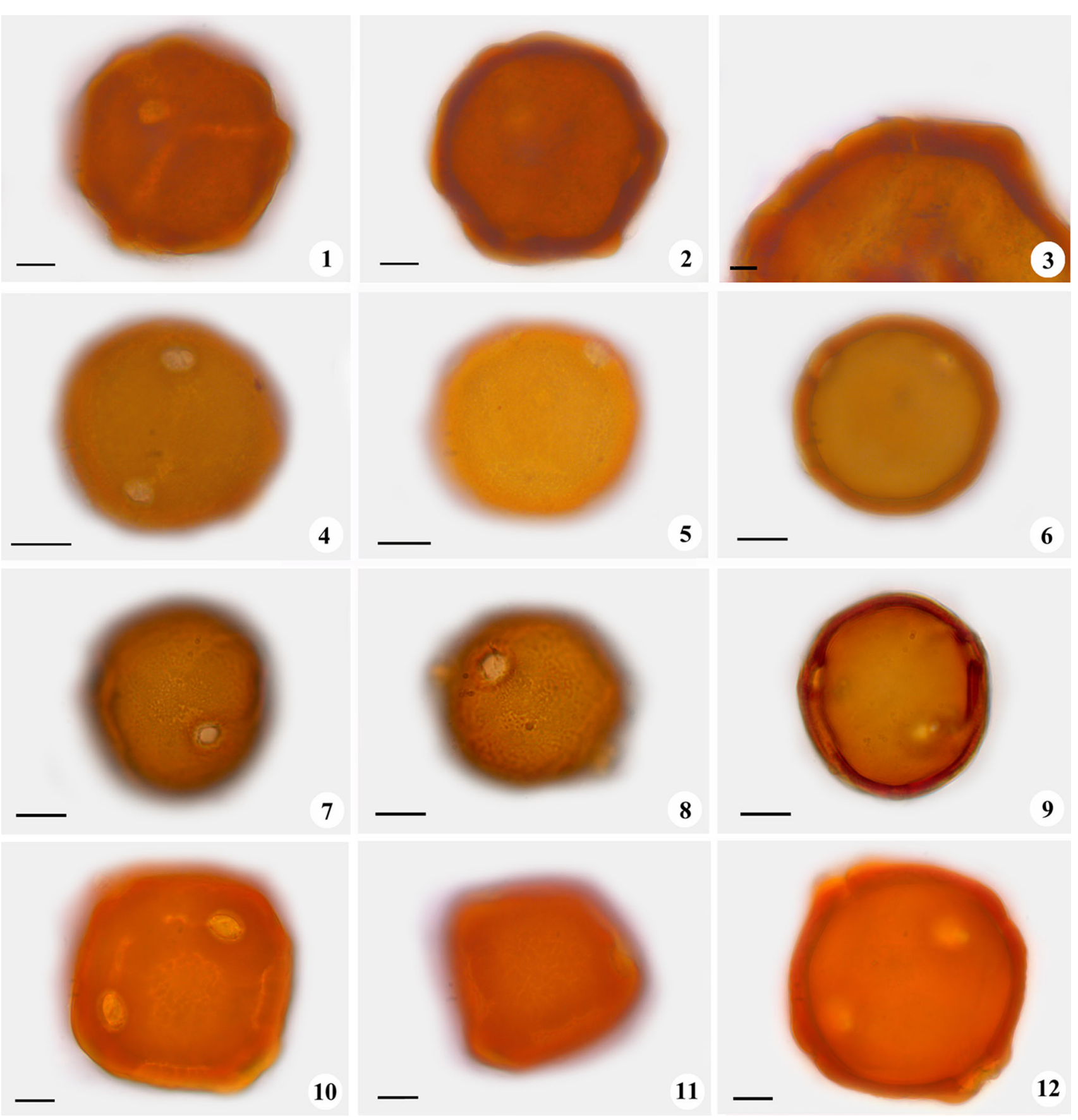

Figs. 1-12 Photomicrographs of the pollen grains of Banisteriopsis C.B.Rob. ex Small (Malpighiaceae). 1-3 B. argyrophylla (A. Juss.) B. Gattes. 1 General aspect, aperture and ornamentation. 2 General aspect, optical section. 3 Exine, optical section. 4-6 B. muricata Cavanilles. 4 General aspect, aperture. 5 General aspect, ornamentation. 6 General aspect, optical section. 7-9 B. nummifera (A. Juss.)
B.Gates. 7 General aspect, aperture. 8 General aspect, ornamentation. 9 General aspect, optical section. 10-12 B. oxyclada (A. Juss.) B. Gattes. 10 General aspect, aperture. 11 General aspect, ornamentation. 12 General aspect, optical section. Bar $=5 \mu \mathrm{m} \mathrm{(3);} 10 \mu \mathrm{m}(\mathbf{1}-\mathbf{2}$, 4-12) 


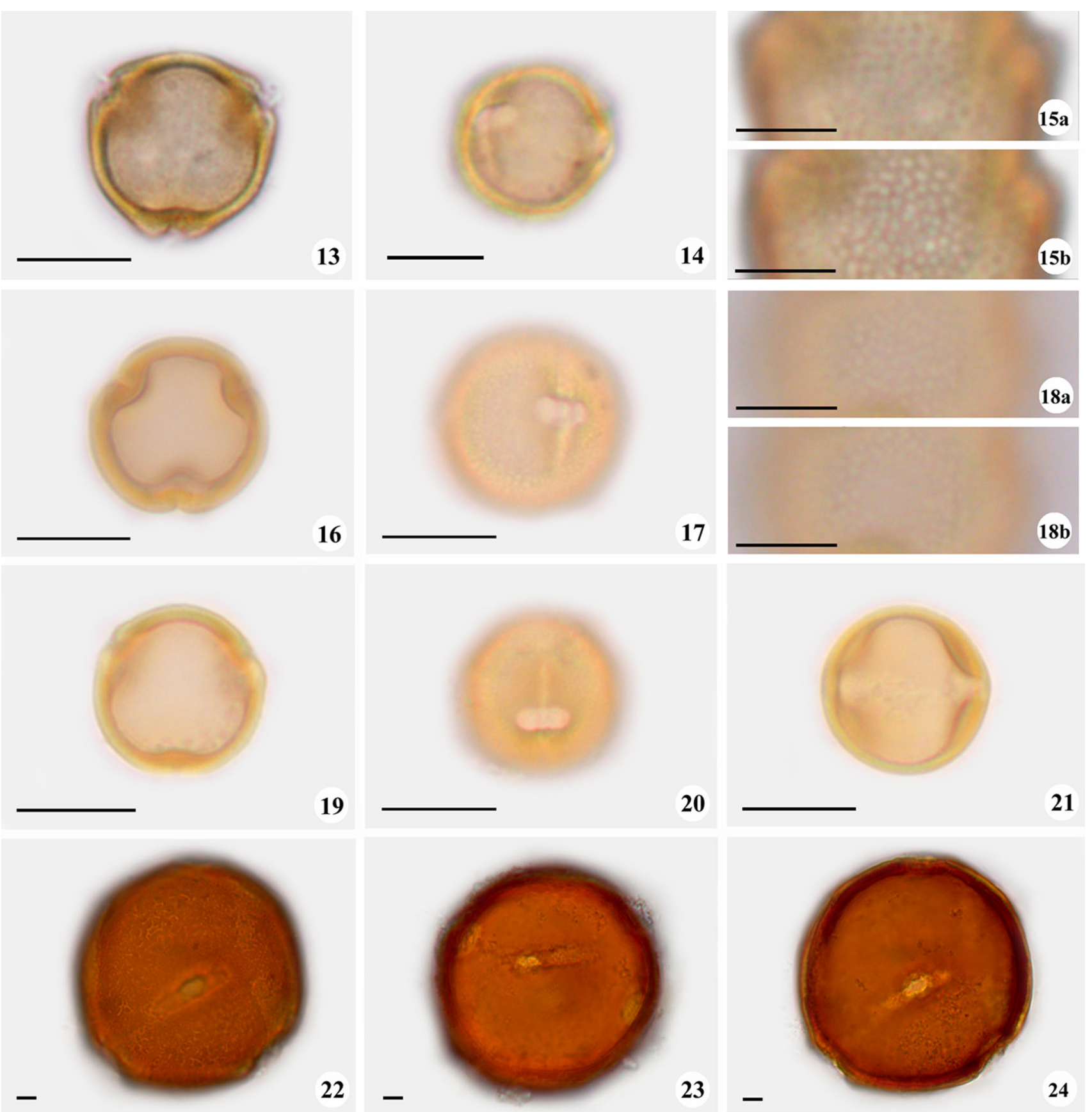

Figs. 13-24 Photomicrographs of the pollen grains of Byrsonima Rich. ex Kunth and Diplopterys A. Juss. (Malpighiaceae). 13-15 Byrsonima crassifolia (L.) Kunth. 13 Polar view, optical section 14 Equatorial view, aperture. 15a, b Ornamentation in high and low focus. 16-18 Byrsonima intermedia A. Juss. 16 Polar view, optical section 17 Equatorial view, aperture. 18a, b Ornamentation in high and low focus. 19-21 Byrsonima verbascifolia (L.) Rich. 19 Polar view, optical section 20 Equatorial view, aperture. 21 Equatorial view, optical section 22-24 Diplopterys pubipetala (A. Juss.) W.R.Anderson \& C.Davis. 22 General aspect, aperture. 23 General aspect, ornamentation. 24 General aspect, optical section. Bar $=5 \mu \mathrm{m}(\mathbf{1 5}, \mathbf{1 8}) ; 10 \mu \mathrm{m}(\mathbf{1 3}-\mathbf{1 4}, \mathbf{1 6}-\mathbf{1 7}, \mathbf{1 9}-\mathbf{2 4})$ 


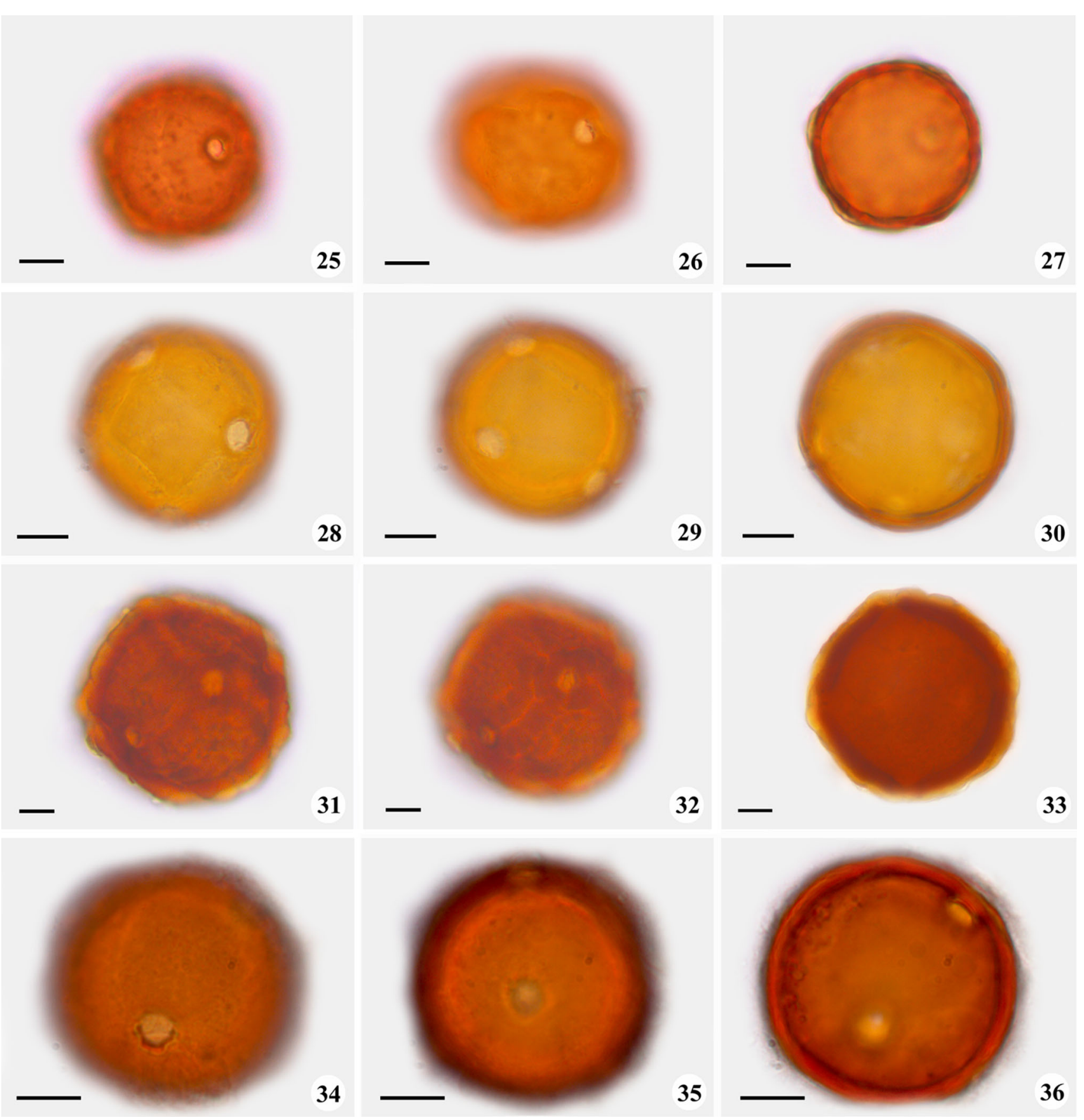

Figs. 25-36 Photomicrographs of the pollen grains of Heteropterys Kunth, Mascagnia Bertero, Peixotoa A. Juss., and Stigmaphyllon A. Juss. (Malpighiaceae). 25-27 Heteropterys aceroides Griseb. 25 General aspect, aperture and ornamentation. 26 General aspect, ornamentation. 27 General aspect, optical section 28-30 Mascagnia cordifolia (A. Juss.) Griseb. 28 General aspect, aperture. 29 General aspect, ornamentation. 30 General aspect, optical section 31-33 Peixotoa tomentosa A. Juss. 31 General aspect, aperture. 32 General aspect, ornamentation. 33 General aspect, optical section 34-36 Stigmaphyllon lalandianum A. Juss. 34 General aspect, aperture. 35 General aspect, ornamentation. 36 General aspect, optical section. Bar $=10 \mu \mathrm{m}$ 

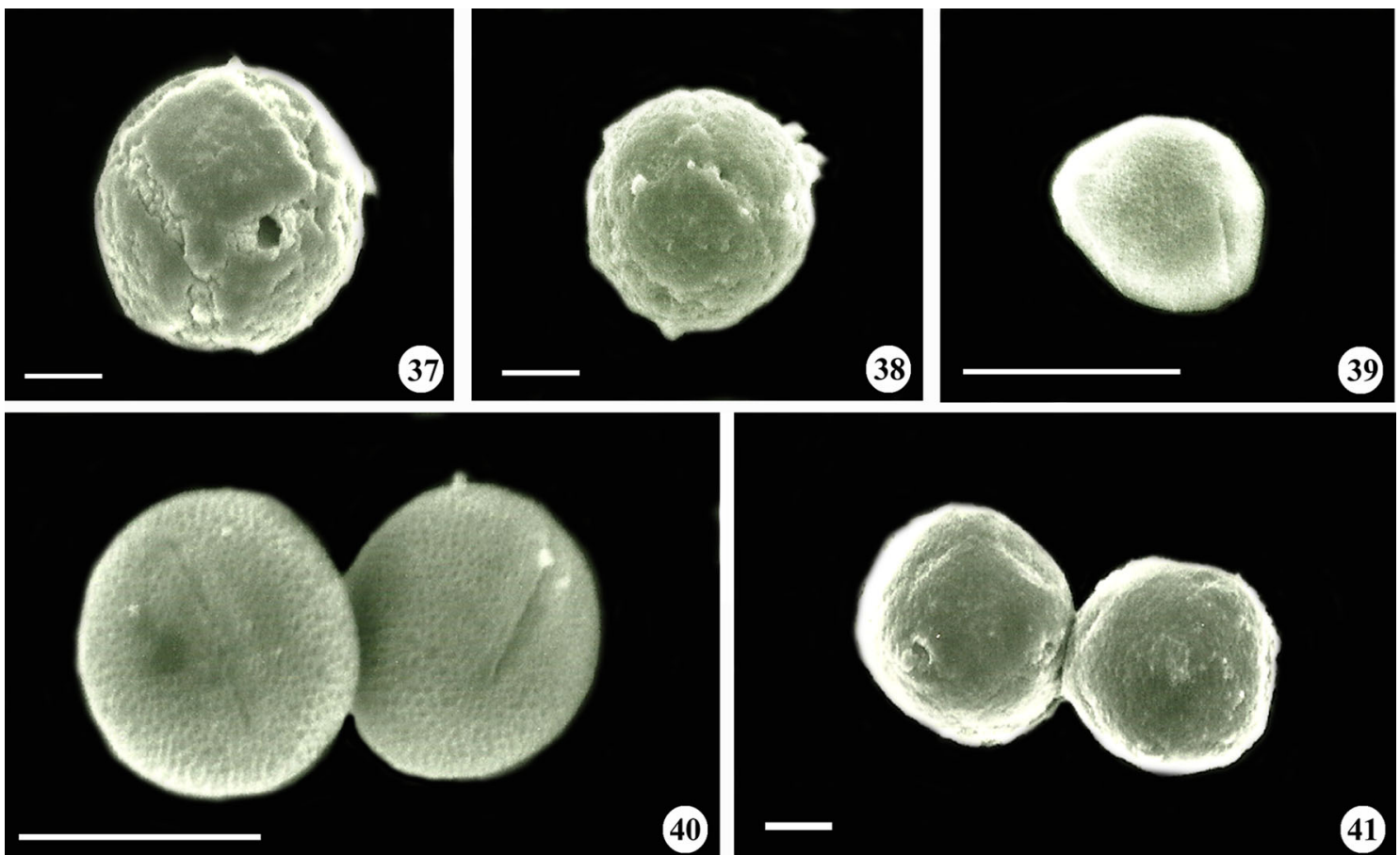

(40)
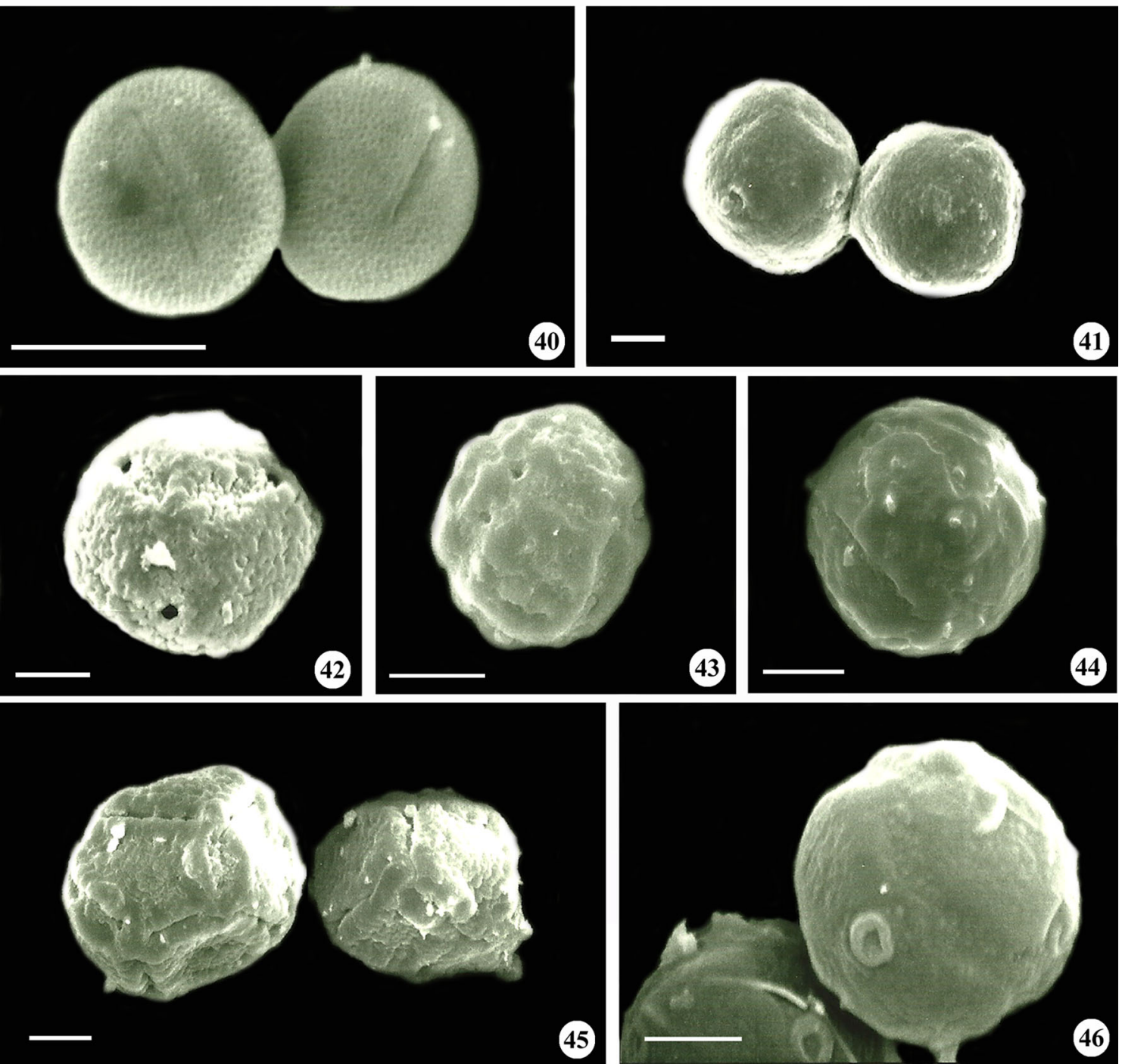

Figs. 37-46 Electron micrographs of the pollen grains of Malpighiaceae. 37-38 Banisteriopsis oxyclada (A. Juss.) B. Gattes. 37 General aspect, apertures. 38 General aspect, ornamentation. 39 Byrsonima crassifolia (L.) Kunth, ornamentation. 40 Byrsonima intermedia A. Juss., apertures and ornamentation. 41-42 Diplopterys pubipetala (A. Juss.) W.R.Anderson \& C.Davis. 41 general aspect, ornamentation.

or isopolar, small to large, with circular to quadrangular amb, oblate-spheroidal to prolate-spheroidal, tricolporate with long colpi and lalongate endoaperture or $6-(7-8)$ -
42 General aspect, apertures. 43 Heteropterys aceroides Griseb., ornamentation. 44 Mascagnia cordifolia (A. Juss.) Griseb., amb and ornamentation. 45 Peixotoa tomentosa A. Juss., ornamentation. 46 Stigmaphyllon lalandianum A. Juss., apertures and ornamentation. Bar $=10 \mu \mathrm{m}$

porate with or without colpoids and aspides, psilate-rugulate, rugulate or microreticulate exine, sexine thicker than nexine in most species. 
Pollen key to Malpighiaceae species

1. Isopolar and colporate pollen grains, microreticulate exine . 2

2. Endoaperture constricted in the median region, exine $\geq 2,01 \mu \mathrm{m}$........ Byrsonima intermedia.

$2^{\prime}$. Endoaperture not constricted in the median region, exine $\leq 2,00 \mu \mathrm{m}$

3. Oblate-spheroidal pollen grains, circular $\mathrm{amb}$, width of endoaperture $\geq 5,01 \mu \mathrm{m}$ Byrsonima verbascifolia.

$3^{\prime}$. Prolate-spheroidal pollen grains, subcircular $\mathrm{amb}$, width of endoaperture $\leq 5,00 \mu \mathrm{m}$. Byrsonima crassifolia.

$1^{\prime}$. Apolar and porate pollen grains, psilate-rugulate or rugulate exine .. 4

4. Pollen grains 7-porate Diplopterys pubipetala.

4'. Pollen grains 6- or 8-porate 5

5. Pollen grains only 8 -porate

6. Circular amb, aperture with inconspicuous colpoids, small regular in exile ................... Mascagnia cordifolia.

6'. Subcircular amb, aperture with conspicuous colpoids, large rugulae in exine .............. Peixotoa tomentosa.

5'. Pollen grains 6-porate or 6(8)-porate ..... 7

7. Exine ornamentation psilate-rugulate with small rugulae

.............Stigmaphyllon lalandianum.

$7^{\prime}$. Exine ornamentation rugulate with psilate areas

8. Pollen grains 6(8)- porate

Heteropterys aceroides.

8'. Pollen grains only 6-porate ........ 9

9. Aperture of pollen grains with conspicuous colpoids ...... 10

10. Large pollen grains, sexine $<$ nexine

Banisteriopsis argyrophylla.

10'. Medium pollen grains, sexine $>$ nexine

....Banisteriopsis oxyclada.

$9^{\prime}$. Aperture of pollen grains with inconspicuous colpoids ...... 11
11. Pori with aspides, sexine $<$ nexine

.Banisteriopsis nummifera.

$11^{\prime}$. Pori without aspides, sexine $>$ nexine

... Banisteriopsis muricata.

Banisteriopsis C.B.Rob. ex small (Figs. 1-12, 37-38, Tables 1, 3)

Apolar pollen grains, medium to large (B. argyrophylla, Table 1), circular to cuboidal (B. oxyclada, Figs. 10-11), 6-porate, with colpoids in the pori, conspicuous in B. argyrophylla (Fig. 1) and B. oxyclada (Figs. 10-11), and inconspicuousin B. muricata (Figs. 4-5) and B. nummifera (Figs. 78). Pori with aspides (B. nummifera, Figs. 7-8, B. oxyclada, Fig. 12). Exine ornamentation rugulate with psilate areas and granules, sexine thicker than nexine (B. muricata and B. oxyclada) or nexine thicker than sexine (B. argyrophylla and $B$. nummifera, Table 3). In SEM we can observe psilate areas near the colpoids and granules within these (Figs. 37-38).

Studied species: Banisteriopsis argyrophylla (A. Juss.) B. Gattes (Figs. 1-3); Banisteriopsis muricata Cavanilles (Figs. 4-6); Banisteriopsis nummifera (A. Juss.) B. Gates (Figs. 7-9); Banisteriopsis oxyclada (A. Juss.) B. Gattes (Figs. 10-12, 37-38).

Byrsonima Rich. ex Kunth (Figs. 13-21, 39-40, Tables 2, 3)

Isopolar and small pollen grains, circular to subcircular amb (B. crassifolia, Fig. 13), oblate-spheroidal to prolatespheroidal, 3-colporate, long and narrow colpi, without margo and rounded ends, lalongate endoapertures sometimes constricted (B. intermedia, Fig. 17) and also with rounded ends. Microreticulate exine, homobrocate (Figs. 15, 18). Sexine thicker than nexine (Table 3). Under SEM, it is observed the homobrocate microreticulum and a slightly psilate area near the apertures (Figs. 39-40).

Studied species: Byrsonima crassifolia (L.) Kunth (Figs. 13-15, 39); Byrsonima intermedia A. Juss. (Figs. 16-18, 40); Byrsonima verbascifolia (L.) Rich. (Figs. 19-21).

\section{Diplopterys A. Juss (Figs. 22-24, 41-42, Table 1)}

Apolar and medium pollen grains (Table 1), circular, 7-porate with short colpoids in the pori (Figs. 22-24), pori without aspides. Rugulate exine with psilate areas mainly near the colpoids (Fig. 22). Nexine thicker than sexine. The 
Table 1 Quantitative data of pollen grains of Banisteriopsis C.B. Rob. ex Small, Diplopterys (A. Juss.) W.R., Heteropterys Kunth, Mascagnia Bertero, Peixotoa A. Juss., and Stigmaphyllon A. Juss. (Malpighiaceae), $n=25$

$R$ range, $x$ mean $(\mu \mathrm{m}), s_{x}$ standard deviation $(\mu \mathrm{m})$, $s$ standard error $(\mu \mathrm{m}), C I$ confidential interval in $95 \%$ $(\mu \mathrm{m}), V$ coefficient of variability (\%)

Table 2 Quantitative data of pollen grains of Byrsonima Rich. ex Kunth (Malpighiaceae), $n=25$

$R$ range, $x$ mean $(\mu \mathrm{m}), s_{x}$ standard deviation $(\mu \mathrm{m})$, $s$ standard error $(\mu \mathrm{m}), C I$ confidential interval in $95 \%$ $(\mu \mathrm{m}), V$ coefficient of variability (\%)

\begin{tabular}{llllr}
\hline Species & $(\mathrm{R}) x \pm s_{x}$ & \multicolumn{1}{l}{ S } & $\mathrm{V}$ \\
\hline Diameter I & & & & \\
B. argyrophylla & $(47.50-57.50) 51.50 \pm 0.46$ & 2.28 & $(50.56-52.44)$ & 4.43 \\
B. oxyclada & $(32.50-45.00) 39.10 \pm 0.61$ & 3.05 & $(37.84-40.36)$ & 7.80 \\
B. muricata & $(27.50-40.00) 35.20 \pm 0.72$ & 3.60 & $(33.72-36.68)$ & 10.23 \\
B. nummifera & $(32.50-45.00) 37.80 \pm 0.55$ & 2.73 & $(36.67-38.93)$ & 7.22 \\
D. pubipetala & $(40.00-47.50) 44.80 \pm 0.48$ & 2.41 & $(43.81-45.79)$ & 5.38 \\
H. aceroides & $(30.00-42.50) 37.20 \pm 0.63$ & 3.17 & $(35.89-38.51)$ & 8.53 \\
M. cordifolia & $(25.00-45.00) 34.70 \pm 0.82$ & 4.10 & $(33.01-36.39)$ & 11.82 \\
P. tomentosa & $(40.00-60.00) 49.50 \pm 0.89$ & 4.45 & $(47.67-51.33)$ & 8.99 \\
S. lalandianum & $(32.50-40.00) 37.40 \pm 0.34$ & 1.69 & $(36.70-38.10)$ & 4.52 \\
Diameter II & & & & \\
B. argyrophylla & $(47.50-57.50) 51.40 \pm 0.58$ & 2.89 & $(50.21-52.59)$ & 5.63 \\
B. oxyclada & $(35.00-42.50) 39.00 \pm 0.50$ & 2.50 & $(37.97-40.03)$ & 6.41 \\
B. muricata & $(27.50-40.00) 34.70 \pm 0.70$ & 3.49 & $(33.26-36.14)$ & 10.04 \\
B. nummifera & $(32.50-45.00) 38.30 \pm 0.64$ & 3.20 & $(36.98-39.62)$ & 8.37 \\
D. pubipetala & $(37.50-47.50) 44.80 \pm 0.51$ & 2.54 & $(43.75-45.85)$ & 5.68 \\
H. aceroides & $(37.50-40.00) 38.00 \pm 0.48$ & 2.39 & $(37.01-38.99)$ & 6.30 \\
M. cordifolia & $(30.00-47.50) 37.50 \pm 0.75$ & 3.75 & $(35.96-39.05)$ & 10.00 \\
P. tomentosa & $(40.00-62.50) 50.45 \pm 0.98$ & 4.88 & $(48.44-52.46)$ & 9.67 \\
S. lalandianum & $(35.00-41.25) 37.65 \pm 0.40$ & 1.99 & $(36.83-38.47)$ & 5.28 \\
\hline
\end{tabular}

\begin{tabular}{lcccr}
\hline Species & $(R) x \pm s_{x}$ & $s$ & CI & $V$ \\
\hline $\begin{array}{l}\text { Equatorial diameter in polar view } \\
\text { B. crassifolia }\end{array}$ & $(12.50-17.50) 14.05 \pm 0.31$ & 1.54 & $(13.41-14.69)$ & 10.98 \\
B. intermedia & $(12.50-17.50) 14.55 \pm 0.28$ & 1.39 & $(13.98-15.12)$ & 9.57 \\
B. verbascifolia & $(12.50-15.00) 13.90 \pm 0.25$ & 1.27 & $(13.38-14.42)$ & 9.11 \\
Polar diameter in equatorial view & & & \\
B. crassifolia & $(12.50-17.50) 14.40 \pm 0.26$ & 1.31 & $(13.86-14.94)$ & 9.08 \\
B. intermedia & $(12.50-17.50) 14.50 \pm 0.29$ & 1.44 & $(13.91-15.09)$ & 9.95 \\
B. verbascifolia & $(12.50-15.00) 13.60 \pm 0.25$ & 1.27 & $(13.08-14.12)$ & 9.31 \\
Equatorial diameter in equatorial view & $(12.50-15.00) 13.75 \pm 0.25$ & 1.25 & $(13.24-14.27)$ & 9.09 \\
B. crassifolia & $(12.50-17.50) 14.30 \pm 0.27$ & 1.35 & $(13.74-14.86)$ & 9.47 \\
B. intermedia & $(12.50-15.00) 13.80 \pm 0.25$ & 1.27 & $(13.27-14.33)$ & 9.24 \\
B. verbascifolia & & & & \\
\hline
\end{tabular}

pollen grains of Diplopterys pubipetala present psilate areas in the ornamentation near the apertures, and small granules within the colpoids. (Figs. 41-42).

Studied species: Diplopterys pubipetala (A. Juss.) W. R. Anderson \& C. Davis (Figs. 22-24, 41-42).

Heteropterys Kunth (Figs. 25-27, 43, Tables 1, 3)

Apolar and medium pollen grains (Table 1), circular (Fig. 27), 6-(8)-porate, with inconspicuous colpoids in the pori (Figs. 25-26), pori without aspides. Rugulate exine with psilate areas irregularly distributed across the pollen grain surface. Sexine thicker than nexine. When observed under SEM, the pollen grains of Heteropterys aceroides have large rugula with psilate areas (Fig. 43).

Studied species: Heteropterys aceroides Griseb (Figs. 25-27, 43).

Mascagnia Bertero (Figs. 28-30, 44, Tables 1, 3)

Apolar and medium pollen grains (Table 1), circular (Fig. 30), 8-porate, with inconspicuous colpoids in the pori 
Table 3 Measures (in $\mu \mathrm{m}$ ) of Malpighiaceae pollen grains, apertures and exine. $n=10$
Pori pori diameter, Ex exine thickness, Sex sexine thickness, Nex nexine thickness, WCI width colpus index

\begin{tabular}{|c|c|c|c|c|c|c|c|c|c|}
\hline \multirow[t]{2}{*}{ Species } & \multirow[t]{2}{*}{ Pori } & \multicolumn{2}{|l|}{ Colpus } & \multicolumn{2}{|c|}{ Endoaperture } & \multirow[t]{2}{*}{ Ex } & \multirow[t]{2}{*}{ Sex } & \multirow[t]{2}{*}{ Nex } & \multirow[t]{2}{*}{ WCI } \\
\hline & & Length & Width & Length & Width & & & & \\
\hline Banisteriopsis argyrophylla & 7.64 & - & - & - & - & 6.08 & 2.94 & 3.14 & - \\
\hline Banisteriopsis muricata & 3.43 & - & - & - & - & 3.53 & 2.45 & 1.08 & - \\
\hline Banisteriopsis nummifera & 5.31 & - & - & - & - & 2.75 & 1.08 & 1.67 & - \\
\hline Banisteriopsis oxyclada & 4.21 & - & - & - & - & 3.24 & 2.06 & 1.18 & - \\
\hline Byrsonima crassifolia & - & 11.50 & 1.00 & 2.00 & 4.00 & 1.03 & 0.70 & 0.33 & 13.75 \\
\hline Byrsonima intermedia & - & 13.04 & 1.30 & 1.73 & 5.20 & 2.17 & 1.30 & 0.87 & 11.00 \\
\hline Byrsonima verbascifolia & - & 12.60 & 0.48 & 1.76 & 9.13 & 1.66 & 1.04 & 0.62 & 28.75 \\
\hline Diplopterys pubipetala & 5.49 & - & - & - & - & 9.13 & 2.47 & 6.66 & - \\
\hline Heteropteris aceroides & 3.65 & - & - & - & - & 3.77 & 2.30 & 1.47 & - \\
\hline Mascagnia cordifolia & 3.11 & - & - & - & - & 8.04 & 3.04 & 5.00 & - \\
\hline Peixotoa tomentosa & 4.41 & - & - & - & - & 8.04 & 3.04 & 5.00 & - \\
\hline Stigmaphyllon lalandianum & 4.70 & - & - & - & - & 3.29 & 1.67 & 1.62 & - \\
\hline
\end{tabular}

(Figs. 28-29), pori without aspides. Regulate exine with small regular distributed across the pollen grain surface. Nexine thicker than sexine (Table 3). Under SEM, we can observe large regulate areas in the ornamentation (Fig. 44).

Studied species: Mascagnia cordifolia (A. Juss.) Griseb (Figs. 28-30, 44).

Peixotoa A. Juss (Figs. 31-33, 45, Tables 1, 3)

Apolar, medium to large pollen grains (Table 1), subcircular (Fig. 31), 8-porate with conspicuous colpoids in the pori (Figs. 31-32), pori without aspides. Rugulate exine with thicker and psilate areas near the colpoids (Figs. 3132). Nexine thicker than sexine (Table 3). Under SEM, we observed large and irregular rugulae distributed throughout the pollen grain ornamentation (Fig. 45).

Studied species: Peixotoa tomentosa A. Juss. (Figs. 31$33,45)$.

Stigmaphyllon A. Juss. (Figs. 34-36, 46, Tables 1, 3)

Apolar and medium pollen grains (Table 1), circular (Fig. 36), 6-porate with inconspicuous colpoids in the pori (Figs. 34, 36), pori with aspides (Figs. 35, 46). Psilaterugulate exine with uniform and small rugulae throughout the pollen grain (Fig. 34). Sexine slightly thicker than nexine (Table 3). When analyzed under SEM, we can see small rugulae in the pollen grain surface, granulate areas in colpoids membrane, and a prominently aspis in the pore (Fig. 46).

Studied species: Stigmaphyllon lalandianum A. Juss. (Figs. 34-36, 46).
Analysis of quantitative data

When we analyzed the mean and confidence interval of the pollen grain diameters (Fig. 47a, b), we clearly observe the distinction of three separate groups considering the pollen size. The first group is represented by the Byrsonima species, which have smaller pollen grains, being Byrsonima intermedia with larger pollen grains. These species are not separated from each other by the values of diameters in this group.

The larger diameters of the pollen grains are observed for species Peixotoa tomentosa and Banisteriopsis argyrophylla, which stand out from the other species concerning these values.

Pollen grains with intermediary diameters values were observed in the other Banisteriopsis species along with Mascagnia cordifolia, Heteropterys aceroides, and Stigmaphyllon lalandianum. These species form a continuous group and cannot be separated from each other. An outstanding position is given to Diplopterys pubipetala which appears among the group of species with intermediate sizes and the two largest species observed (Fig. 47a, b).

The quantitative data of the pollen grains were exploited by PCA in order to identify the link between the species studied (Fig. 48). This analysis summarized in their two axes $98.09 \%$ of total data variability.

The first axis of the principal component analysis was the most significant for the species ordination and summarized $92.91 \%$ of the total variability of the analyzed data. This component explained the variance based mainly on the values of the diameters in polar view (EDPV), length of colpus (CLEN), and width of endoaperture (ELAR_Table 4), i.e. these variables influenced the 

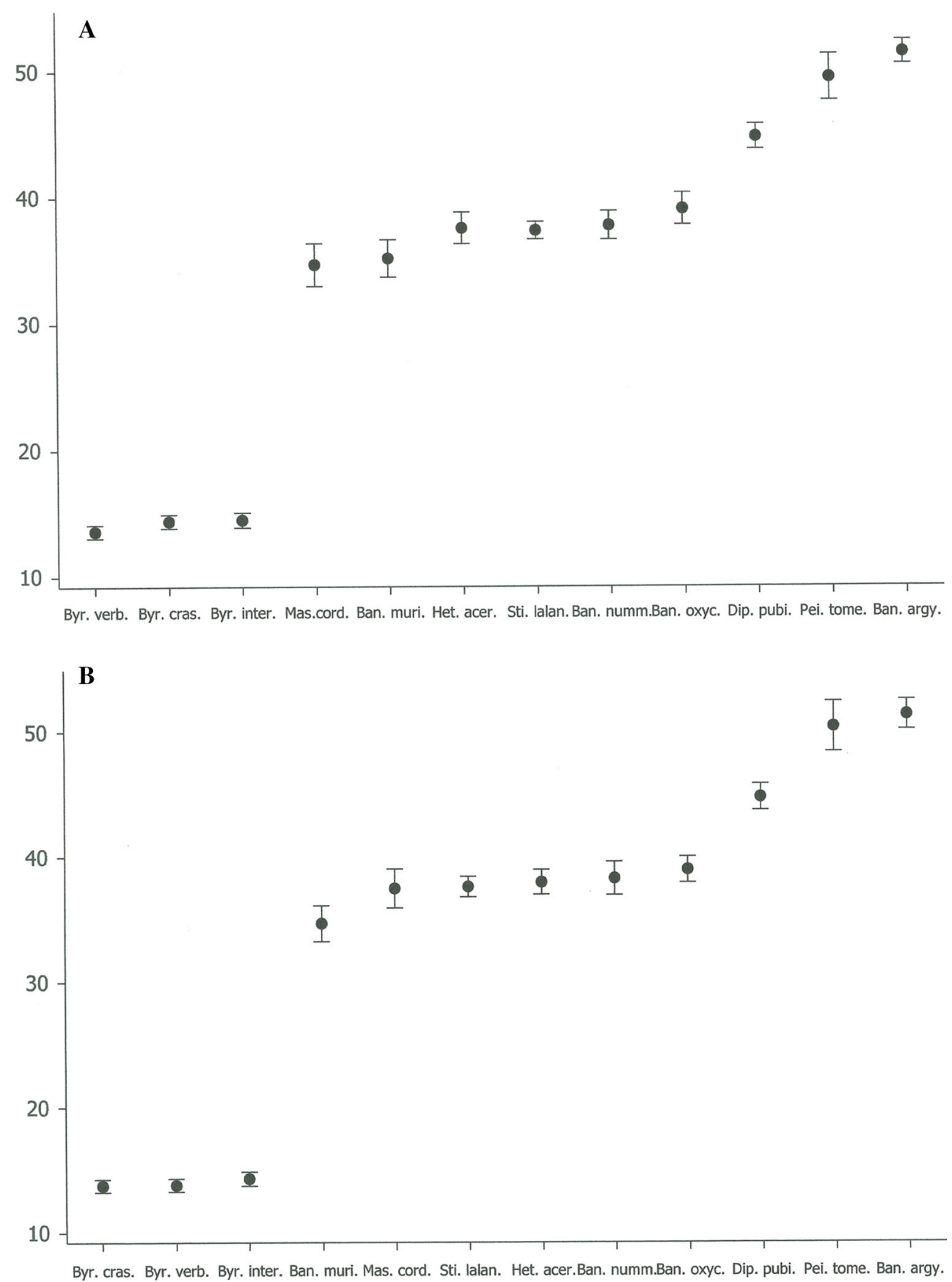

Fig. 47 Representation of confidence interval of mean in $95 \%$ of the pollen grains of Malpighiaceae. a Diameter I or polar diameter in equatorial view. b Diameter II or equatorial diameter in equatorial view. The higher and lower boundaries showing the confidence interval; the average circle showing the arithmetic mean. Ban. argy. = Banisteriopsis argyrophylla, Ban. muri. = Banisteriopsis muricata, Ban. numm. = Banisteriopsis nummifera, Ban.

placement of the Byrsonima species on the positive side (on the right) of the axis 1 , thereby separating the apolar and polar pollen grains by metric values of these variables and also width of colpus and length of endoaperture (Fig. 48). oxyc. $=$ Banisteriopsis oxyclada , Byr.cras. $=$ Byrsonima crassifoliai Byr. inter. = Byrsonima intermedia, Byr. verb. = Byrsonima verbascifolia, Dip. $\quad$ pubi. = Diplopterys pubipetala, Het. acer. $=$ Heteropterys aceroides, Mas. cord. = Mascagnia cordifolia, Pei. tome. $=$ Peixotoa tomentosa, and Sti. lalan. = Stigmaphyllon lalandianum. The values are in $\mu \mathrm{m}$

On the negative side of axis 1 , it is possible to observe the species with higher values of diameters of pollen grains and pore diameter; they are divided into two distinct groups, separated by the variables related to the axis 2 of the PCA (characteristics of exine thickness). 


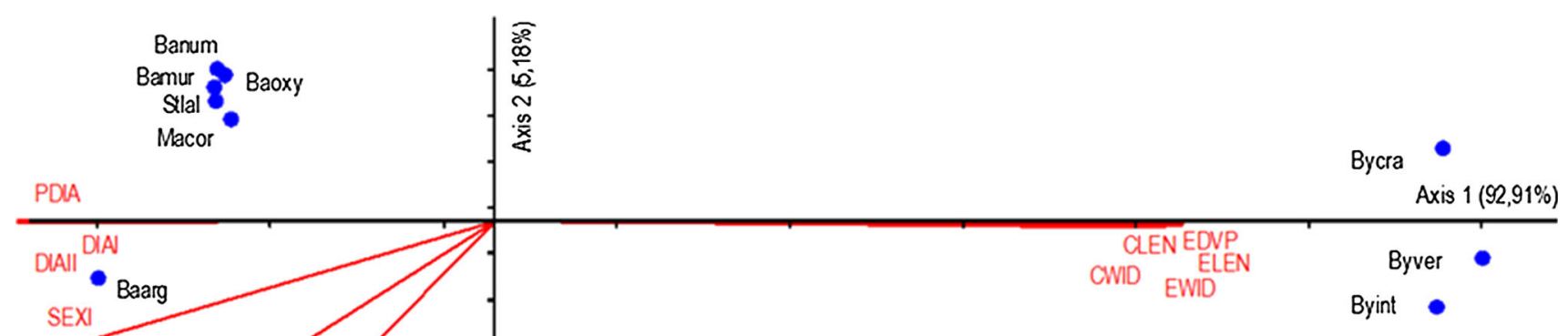

Fig. 48 Principal component analysis performed with the pollen metrical variables from Malpighiaceae species. Baarg = Banisteriopsis argyrophylla, Bamur = Banisteriopsis muricata, Banum = Banisteriopsis nummifera, Baoxy $=$ Banisteriopsis oxyclada, Bycra $=$

Table 4 Pearson and Kendall correlation coefficients for pollen grains metric variables of the first and the second axis of PCA ordination in Malpighiaceae species

\begin{tabular}{lcr}
\hline Variables & \multicolumn{2}{l}{ Principal components } \\
\cline { 2 - 3 } & Axis 1 & Axis 2 \\
\hline EDVP & 0.5295 & -0.1621 \\
DIAI & -0.2062 & -0.0191 \\
DIAII & -0.2093 & -0.0376 \\
PDIA & -0.3368 & 0.0534 \\
CLEN & 0.5050 & -0.1641 \\
CWID & 0.1238 & -0.0417 \\
ELEN & 0.2024 & -0.0510 \\
EWID & 0.3744 & -0.1483 \\
EXIN & -0.1719 & -0.5802 \\
SEXI & -0.1004 & -0.2303 \\
NEXI & -0.1697 & -0.7254 \\
\hline
\end{tabular}

The second component explained only $5.18 \%$ of the variability of the species studied, the values of nexine (NEXI) and exine (EXIN) were important for the ordering of species that appear on the negative side of the axis (Diplopterys pubipetala, Peixotoa tomentosa, Heteropterys aceroides, and Banisteriopsis argyrophylla). As we could see in the graph (Fig. 48), the axis 2 contributed little to the ordering of the species analyzed, nevertheless, the values of the exine of pollen grains of Malpighiaceae were important in the grouping of species along this axis.

\section{Discussion}

Pollen data about the Malpighiaceae genera analyzed were previously characterized in the studies of SalgadoLabouriau (1973), Anderson (1982), Makino (1986),
Byrsonima crassifoliai Byint $=$ Byrsonima intermedia, Byver $=$ Byrsonima verbascifolia, Dipub $=$ Diplopterys pubipetala, Heace $=-$ Heteropterys aceroides, Macor = Mascagnia cordifolia, Petom = Peixotoa tomentosa , and Stlal = Stigmaphyllon lalandianum

Roubik and Moreno (1991), Makino-Watanabe et al. (1993a), Melhem et al. (2003), Magalhães-e-Silva (2007), Gonçalves-Esteves et al. (2007) e Sousa et al. (2010) Table 5.

To Banisteriopsis campestris (A. Juss.) Little, SalgadoLabouriau (1973) described spherical pollen grains, 6-porate, with colpoids, and obscure ornamentation. The author also highlights the similarity between the pollen grain of Banisteriopsis campestris and Peixotoa reticulata. The data of Banisteriopsis in our study support the description of Salgado-Labouriau (1973) for Banisteriopsis campestris, however, the ornamentation was here defined as rugulate, and we observed a difference in the number of apertures when comparing the pollen grains of this genus with Peixotoa.

Makino (1986) showed variations in the number of apertures ((4-5) 6-porate) and ornamentation (granulate, microreticulate, and rugulate) when she studied the pollen grains of Banisteriopsis, the same is true for B. cornifolia (HBK) C.B.Robinson ex Small, described by Roubik and Moreno (1991) as 6-8-porate and psilate. Though we have analyzed other species, the pollen data found generally agree with the data of these authors, but we did not observe the variations of aperture and ornamentation, describing here 6-porate and rugulate pollen grains.

The pollen grains of a considerable number of Banisteriopsis species were analyzed by Makino-Watanabe et al. (1993a), the authors described pollen grains with a variable number of apertures (between 3 and 10 pori), with colpoids or not, psilate, microreticulate, reticulate, or rugulate. In this paper, Makino-Watanabe et al. (1993a) analyzed the four species studied by us, reporting the values of pollen grain diameter and pore diameters superior to those assessed herein (except for the pore diameters of B. muricata and $B$. nummifera). The authors also indicated the rugulate ornamentation with psilate areas only for $B$. 
Table 5 Important pollen studies in Malpighiaceae which include the analyzed genera in this study

\begin{tabular}{|c|c|c|c|c|c|c|c|}
\hline & $\begin{array}{l}\text { Banisteriopsis } \\
\text { C.B.Rob. ex Small }\end{array}$ & $\begin{array}{l}\text { Byrsonima Rich. } \\
\text { ex Kunth }\end{array}$ & $\begin{array}{l}\text { Diplopterys } \\
\text { A. Juss. }\end{array}$ & $\begin{array}{l}\text { Heteropterys } \\
\text { Kunth }\end{array}$ & $\begin{array}{l}\text { Mascagnia } \\
\text { Bertero }\end{array}$ & $\begin{array}{l}\text { Peixotoa } \\
\text { A. Juss. }\end{array}$ & $\begin{array}{l}\text { Stigmaphyllon } \\
\text { A. Juss. }\end{array}$ \\
\hline $\begin{array}{l}\text { Salgado-Labouriau } \\
\text { (1973) }\end{array}$ & 1 & 2 & - & - & - & 1 & - \\
\hline Anderson (1982) & - & - & - & - & - & 2 & - \\
\hline Makino (1986) & 4 & 2 & - & 3 & - & - & - \\
\hline $\begin{array}{l}\text { Roubik and Moreno } \\
\text { (1991) }\end{array}$ & 1 & 1 & - & 1 & 2 & - & 4 \\
\hline $\begin{array}{l}\text { Makino-Watanabe } \\
\text { et al. (1993a) }\end{array}$ & 41 & - & - & - & - & - & - \\
\hline Melhem et al. (2003) & - & 1 & - & - & - & - & - \\
\hline $\begin{array}{l}\text { Magalhães-e-Silva } \\
\text { (2007) }\end{array}$ & 2 & 1 & - & 1 & - & 1 & - \\
\hline $\begin{array}{l}\text { Gonçalves-Esteves } \\
\text { et al. (2007) }\end{array}$ & 1 & 1 & - & 6 & - & 1 & 4 \\
\hline Sousa et al. (2010) & - & - & - & 1 & - & - & - \\
\hline This study & 4 & 3 & 1 & 1 & 1 & 1 & 1 \\
\hline
\end{tabular}

- absent genus in the study. The numbers present the number of species

argyrophylla, for other species Makino-Watanabe et al. (1993a) reported pollen grains psilate (B. oxyclada), reticulate-rugulate (in $B$. nummifera) or with obscure exine (for B. muricata).

When analyzing the pollen grains of Banisteriopsis muricata, Magalhães-e-Silva (2007) also indicated variations in the number of apertures and exine ((4-5)6(7)-porate, scabrate) as previously mentioned in other studies. In our study, we observed that the quantitative data described for this species are similar to those reported by Magalhãese-Silva (2007) however 6-porate and rugulate pollen grains were found. We believe that these differences in aperture and exine ornamentation described in the studies are mainly due to the difficulty of observing the pori and colpoids and by the irregularity of the ornamentation on the pollen grain surface.

Gonçalves-Esteves et al. (2007) studied the pollen morphology of Banisteriopsis sellowiana, and have portrayed apolar, medium and cuboidal pollen grains, 6-porate, with colpoids and rugulate with psilate areas in the sexine. Here we found similar pollen data for Banisteriopsis sellowiana, however, there are differences related to the size and shape of the pollen grains when compared with the data of those authors.

The pollen grains of Byrsonima species were described as isopolar, small, 3-colporate with lalongate endoaperture, constricted or not, and reticulate or microreticulate exine by Salgado-Labouriau (1973), Makino (1986), Roubik and Moreno (1991), Melhem et al. (2003), Magalhães-e-Silva (2007), and Gonçalves-Esteves et al. (2007). Our data for Byrsonima crassifolia, B. intermedia, and $B$. verbascifolia confirm the previously published data pollen.

Makino (1986) analyzed the pollen grains of Byrsonima intermedia and observed the endoaperture constriction as seen here. This detail also appears for other species in the genus, e.g. Salgado-Labouriau (1973), Melhem et al. (2003), Gonçalves-Esteves et al. (2007). It is also worth emphasizing that even indicating reticulate ornamentation for Byrsonima species, both Salgado-Labouriau (1973) and Roubik and Moreno (1991) report that the lumen of the reticulum has less $1 \mu \mathrm{m}$, what characterizes microreticulate pollen grains.

Variations in the number of aperture and the exine ornamentation were also observed for the pollen grains of Heteropterys species (Makino 1986; Magalhães-e-Silva 2007; Gonçalves-Esteves et al. 2007). Makino (1986) described the genus pollen grains 3-porate to poliporate (until 12 pores) with psilate, microreticulate and reticulaterugulate exine. Magalhães-e-Silva (2007) observed in Heteropterys catingarum A. Juss. pollen grains 4-6-(7)porate, scabrate, and Gonçalves-Esteves et al. (2007) pollen 6-8-porate with rugulate, psilate, or scabrate sexine in the six species studied by them. However, the studies of Roubik and Moreno (1991) and Sousa et al. (2010) indicate pollen grains 6-porate with psilate or rugulate exine, with no evidence to large variations.

The pollen grains of Heteropterys aceroides examined by us had 6-(8)-pori with conspicuous colpoids and psilaterugulate exine, characteristics also described by Makino (1986) for this specie. Therefore, due to the morphological 
variation presented in the literature about Heteropterys pollen, we suggest that it belongs to an euripalynous genus.

Roubik and Moreno (1991) analyzed the pollen of two Mascagnia species and described their pollen grains as 6-porate, with inconspicuous colpoids if present, and exine ranging from verrucate (in $M$. hippocrateoides ( $\operatorname{Tr} \&$ Planch.) Niedenzu) to psilate (in $M$. nervosa Niedenzu). For Mascagnia cordifolia here analyzed, we observed 8-porate pollen grains, with inconspicuous colpoids and rugulate exine, differing from the results of Roubik and Moreno (1991) about the number of apertures and the exine ornamentation. By comparing these data, we can conclude that there is possibly a variation in pollen morphology to the genus Mascagnia.

Three species of Peixotoa had their pollen grains previously described, $P$. reticulata Griseb. with spherical pollen grains, 6-porate, with irregular colpoids and obscure exine was observed by Salgado-Labouriau (1973). Anderson (1982) describes for P. goiana C. E. Anderson and $P$. parviflora A. Juss. 6-porate and cuboid pollen grains, which he believes to be typical for most of the genera in tribe Banisteriae, we also observe in this paper ornamented colpoids and rugulate exine. There is a variation in the number of apertures in P. tomentosa analyzed here (8-porate) and the species described above, however, the presence of colpoids and ornamentation of exine (rugulate) appears to be a common character for the genus.

Roubik and Moreno (1991) observed variations in pollen morphology for Stigmaphyllon, its pollen grains are medium to large, stephanocolporate (6-colporate) and periporate (6-porate or $>7$-porate), sexine psilate to verrucate, scabrate, or psilate. This variation was also indicated by Gonçalves-Esteves et al. (2007) when observed medium to large pollen grains, apolar, 6-8-10-porate with colpoids and rugulate or rugulate-pilate sexine. The specie analyzed by us showed medium pollen grains, 6-porate with inconspicuous colpoids, pori with aspides and psilaterugulate exine, supporting the pollen data presented by Roubik and Moreno (1991) and Gonçalves-Esteves et al. (2007), confirming the variation in Stigmaphyllon pollen.

For Diplopterys no pollen morphology data were found in literature, and therefore this analysis in Diplopterys pubipetala is the first palynological study.

The data obtained confirm the euripalynous character of the Malpighiaceae, as mentioned before in the papers involving species of the family and emphasize the importance of pollen study in the analyzed genera. We observed pollen morphology particularly similar among the Byrsonima species, which could suggest a stenopalynous genus. In the Banisteriopsis species we found differences about the amb (circular to cuboidal), details of apertures (with or without aspides), and exine (sexine sometimes thicker, sometimes thinner than nexine), that also show a pollen morphology variation in the genus. The quantitative data helped in the separation of species, as evidenced by PCA, and by comparison to other studies with Heteropterys, Mascagnia, Peixotoa, and Stigmaphyllon, we can conclude that these genera also exhibit significant variations in the pollen morphology which could assist in the identification of its species.

Acknowledgments The authors thank the State of São Paulo Research Foundation (FAPESP-2013/11832-7) for the scholarship of the first author, Prof. Dr. F.J. Zara (DBAA-FCAV) by granting the optical photomicroscope used, and Profa. Dra. Luciane O. Crossetti (Instituto de Biociências-UFRGS) by help with the PCA programs.

\section{Appendix: Specimens examined}

Banisteriopsis argyrophylla (A. Juss.) B. Gattes: BRASIL. São Paulo: Novo Horizonte, 25 Mar 2010, N.T. Ranga et al. F03 (SJRP); BRASIL. São Paulo: Sales, 24 May 2008, N.T. Ranga et al. 19 (SJRP); BRASIL. São Paulo: Votuporanga, 15 Mar 2008, N.T. Ranga et al. 26 (SJRP).

Banisteriopsis muricata Cavanilles: BRASIL. São Paulo: Barretos, 05 Mar 2009, N.T. Ranga et al. 21 (SJRP); BRASIL. São Paulo: Taquaritinga, 12 Mar 2009, N.T. Ranga et al. 02 (SJRP).

Banisteriopsis nummifera (A. Juss.) B.Gates: BRASIL. São Paulo: Jaboticabal, 14 Aug 1991, E.H.A. Rodrigues 141 (JABU).

Banisteriopsis oxyclada (A. Juss.) B. Gattes: BRASIL. São Paulo: Ida Iolanda, 30 Jun 2006, N.T. Ranga et al. 45 (SJRP); BRASIL. São Paulo: Macaubal, 05 Apr 2008, N.T. Ranga et al. 01 (SJRP); BRASIL. São Paulo: Onda Verde, 01 Jan 2007, N.T. Ranga et al. 14 (SJRP).

Byrsonima crassifolia (L.) Kunth: BRASIL. Minas Gerais: São Roque de Minas, Serra da Canastra, 14 Jun 2009, B.F. Bueno 005 (JABU).

Byrsonima intermedia A. Juss.: BRASIL. Goiás: Rio Verde, 11 May 2009, A.C. Lofego s/n. (SJRP 30024); BRASIL. Mato Grosso: Itiquira, 03 Jun 2003, R.D. Daud \& P.R. Demite 37 (SJRP); BRASIL. São Paulo: Barretos, 21 Aug 2008, N.T. Ranga et al. 24 (SJRP); BRASIL. São Paulo: Bebedouro, 19 Feb 2009, N.T. Ranga et al. 28 (SJRP).

Byrsonima verbascifolia (L.) Rich.: BRASIL. Goiás: Edealina, 11 May 2009, A.C. Lofego s/n. (SJRP 30017); BRASIL. Mato Grosso: Itiquira, 03 Jun 2003, R.D. Daud \& P.R. Demite 50 (SJRP).

Diplopterys pubipetala (A. Juss.) W. R. Anderson \& C. C. Davis: BRASIL. São Paulo: Birigui, Fazenda Água Branca, 11 Aug 1999, Montilha et al. 31 (SJRP); BRASIL. São Paulo: Sales, Fazenda Água Clara, 24 Aug 1995, M.D.N. Grecco et al. 105 (SJRP). 
Heteropterys aceroides Griseb.: BRASIL. São Paulo: Paulo de Faria, Estação Ecológica de Paulo de Faria, 23 Jun 1993, V. Stranghette 234 (SJRP); BRASIL. São Paulo: Paulo de Faria, Estação Ecológica de Paulo de Faria, 12 Jan 1994, V. Stranghetti 251 (SJRP).

Mascagnia cordifolia (A. Juss.) Griseb.: BRASIL. São Paulo: Campinas, Distrito de Souzas, 22 Jun 1996, K. Santos s/n. (SJRP 30104); BRASIL. São Paulo: José Bonifácio, antiga Fazenda Jacaré, 07 Apr 1995, M.R. Pietrobom da Silva 2270 (SJRP); BRASIL. São Paulo: São José do Rio Preto, Mata dos Macacos, 1 May 1999, F. Tomasetto s/n. (SJRP 29374).

Peixotoa tomentosa A. Juss.: BRASIL. São Paulo: Itirapina, cerrado de Itirapina, 07 May 1962, Homero do Amaral s/n (JABU514).

Stigmaphyllon lalandianum A. Juss.: BRASIL. São Paulo: Jaboticabal, 09 Mar 1991, E.H.A. Rodrigues 129 (JABU).

\section{References}

Amorim AM (2002) Five new species of Heteropterys (Malpighiaceae) from Central and South America. Brittonia 54:217-232

Amorim AM (2003) Estudos taxonômicos em Heteropterys (Malpighiaceae). $\mathrm{PhD}$ Thesis, São Paulo University

Anderson WR (1981) Malpighiaceae. In: Maguire B (ed) The Botany of the Guayana Highland-Part XI. Mem New York Bot Gard 32:21-305

Anderson C (1982) A monograph of the genus Peixotoa (Malpighiaceae). Contrib Univ Mich Herb 15:1-92

Anderson WR (1990) The origin of the Malpighiaceae: the evidence from morphology. Mem N Y Bot Gard 64:210-224

Anderson WR (1993) Chromosome number of neotropical Malpighiaceae. Contrib Univ Mich Herb 19:341-354

Anderson WR (2004) Malpighiaceae (Malpighia family). In: Smith N, Mori SA, Henderson A, Stevenson DW, Heald SV (eds) Flowering plants of the neotropics. Princeton University Press, New Jersey, pp 229-232

Apg III (2009) An update of the phylogeny group classification for the orders and families of flowering plants: APG III. Bot J Linn Soc 161:105-121

Barth OM, Melhem TS (1988) Glossário ilustrado de Palinologia. Editora da Universidade Estadual de Campinas, Campinas

Cameron KM, Chase MW, Anderson WR, Hillis HG (2001) Molecular systematics of Malpighiaceae: evidence form plastid $r b c \mathrm{~L}$ and $m a t \mathrm{~K}$ sequences. Am J Bot 88:1832-1847

Davis CC, Anderson WR (2010) A complete generic phylogeny of Malpighiaceae inferred from nucleotide sequence data and morphology. Am J Bot 97:2031-2048

Davis CC, Anderson WR, Donoghue MJ (2001) Phylogeny of Malpighiaceae: evidence from chloroplast $n d h \mathrm{~F}$ and $t r n \mathrm{~L}-\mathrm{F}$ nucleotide sequences. Am J Bot 88:1830-1846

Davis CC, Bell CD, Mathews S, Donoghue MJ (2002a) Laurasian migration explains Gondwanan disjunctions: evidence from Malpighiaceae. Proc Natl Acad Sci 99:6833-6837

Davis CC, Bell CD, Fritsch PW, Mathews S (2002b) Phylogeny of Acridocarpus-Brachylophon (Malpighiaceae): implications for tertiary tropical floras and Afroasian biogeography. Evolution 56:2395-2405

Davis CC, Fritsch PW, Bell CD, Mathews S (2004) High latitude tertiary migrations of an exclusively tropical clade: evidence from Malpighiaceae. Int J Plant Sci 165:S107-S121

Dutra FV, Santos HD, Ribeiro PC, Gasparino EC (2014) Morfologia polínica em espécies ornamentais de Asteraceae, Ericaceae, Fabaceae, Malpighiaceae, Malvaceae e Rubiaceae. Nucleus $11: 7-17$

Erdtman G (1952) Pollen morphology and plant taxonomy-angiosperms. Alquimist \& Wiksell, Stockholm

Erdtman G (1960) The acetolysis method. A revised description. Sven Bot Tidskr 54:561-564

Faegri G, Iversen J (1966) Textbook of modern pollen analysis, 2nd edn. Scandinavian University Books, Copenhagen

Gasparino EC, Cruz-Barros MAV, Chautems A (2013) Pollen morphology in Brazilian species of Codonanthe (Mart.) Hanst. and Nematanthus Schrader (Gesneriaceae). Grana 52:274-285

Gonçalves-Esteves V, Soares Júnior EF, Mendonça CBF (2007) Palinologia de espécies de Malpighiaceae Juss. ocorrentes nas restingas do Estado do Rio de Janeiro. Hoehnea 34:519-529

Judd WS, Campbell CS, Kellogg EA, Stevens PF, Donoghue MJ (2009) Sistemática Vegetal: um enfoque filogenético, 3a edn. Artmed, Porto Alegre

Kronka FJN, Matsukuma CK, Nalon MA, Delcali IH, Rossi M, Mattos IFA, Shinike MS, Pontinhas AAS (1993) Inventário Florestal do Estado de São Paulo. Instituto Florestal, São Paulo

Lobreau D (1967) Contribution à l'etude du pollen des Malpighiaceae d'Afrique. Pollen Spores 9:241-277

Lobreau D (1968) Le pollen des Malpighiacées d'Afrique et de Madagascar. Étude sur la systematique des genres à la lumiére de nouvelles observations palynologigues. Bull I FAN 30:59-83

Lobreau-Callen D (1983) Analyse de la répartition géographique des Malpighiaceae d'après les caracteres du pollen et de la pollinisation. Bothalia 14:871-881

Magalhães-e-Silva FH (2007) Contribuição à palinologia das Caatingas. PhD Thesis, State University of Feira de Santana, Feira de Santana

Makino WH (1986) Flora polínica da Reserva do Parque Estadual das Fontes do Ipiranga - Família 125-Malpighiaceae. Hoehnea 13:21-30

Makino-Watanabe H (1988) Contribuição ao estudo palinológico das Malpighiaceae A.L. Jussieu do Brasil (Tribo Banisterieae, Subtribo Banisteriinae). PhD Thesis, State University of Campinas

Makino-Watanabe H, Melhem TS, Barth MO (1993a) Morfologia dos grãos de pólen de espécies de Banisteriopsis C.B. Robinson ex Small (Malpighiaceae). Rev Bras Bot 16:47-67

Makino-Watanabe H, Melhem TS, Barth MO (1993b) Morfologia dos grãos de pólen de espécies brasileiras de Janusia A. Juss. e Schwannia Endl. (Malpighiaceae). Hoehnea 20:79-86

Makino-Watanabe H, Melhem TS, Barth MO (1998) Morfologia polínica de Camarea St.-Hil. (Malpighiaceae). Rev Bras Bot $21: 1-6$

Mamede MCH, Amorim AMA, Sebastiani R, Almeida RF (2014) Malpighiaceae. In: Forzza RC (coord) Lista de Espécies da Flora do Brasil. Jardim Botânico do Rio de Janeiro. http://floradobra sil.jbrj.gov.br/jabot/floradobrasil/FB155. Accessed Aug 2014

McCune B, Mefford MJ (1999) PC-ORD. Multivariate analysis of ecological data. MjM Software Design, Oregon

Melhem TS, Cruz-Barros MAV, Corrêa AMS, Makino-Watanabe H, Silvestre-Capelato MSF, Gonçalves-Esteves VL (2003) Variabilidade polínica em plantas de Campos do Jordão (São Paulo, Brasil). Bol Inst Bot 16:1-104 
Myers N, Mittermeier RA, Fonseca GAB, Kent J (2000) Biodiversity hotspots for conservation priorities. Nature 403:853-858

Niendenzu F (1928) Malpighiaceae. In: Engler A (ed) Das Pflanzenreich. Verlag von Wilhelm Engelmann, Leipzig, pp 247-572

Punt W, Hoen PP, Blackmore S, Nilsson S, Le Thomas A (2007) Glossary of pollen and spore terminology. Rev Paleobot Palynol 143:1-81

Ranga NT, Rezende AA, Cavasan O, Toniato MTZ, Cielo-Filho R, Stranghetti V (2012) Caracterização florística de remanescentes de vegetação nativa da região noroeste do Estado de São Paulo. In: Necchi O Jr (ed) Fauna e Flora de fragmentos florestais remanescentes da região Noroeste do Estado de São Paulo. Holos Editora, Ribeirão Preto, pp 105-135

Rao SRS, Sarma V (1992) Morphology of 2-armed trichomes in relation to taxonomy: malpighiales. Feddes Repert 103:559-565

Robertson KR (1972) The malpíghiaceae in the southeastern United States. J Arnold Arbor 53:101-112

Roubik DW, Moreno JE (1991) Pollen and spores of Barro Colorado Island. Missouri Botanical Garden, New York

Salgado-Labouriau ML (1973) Contribuição à Palinologia dos Cerrados. Academia Brasileira de Ciências, Rio de Janeiro
Salgado-Labouriau ML, Vanzolini PE, Melhem TS (1965) Variation of polar axés and equatorial diameters in pollen grains of two species of Cassia. Grana Palynol 6:98-105

Sebastiani R, Cruz-Barros MAV, Corrêa MAS (2014) Palynological study of Janusia A. Juss. and related genera (Malpighiaceae). Braz J Bot. doi:10.1007/s40415-014-0082-1

Shepherd GJ (1996) Fitopac 1: manual do usuário. Departamento de Botânica. Universidade Estadual de Campinas, Campinas

Sousa SM, Reis AC, Gomes SSL, Bernardo KB, Salimena FRG, Viccini LF (2010) Botanical aspects of Heteropterys umbellata (Malpighiaceae): a cytological and palynological approach. An Acad Bras Ciênc 82:869-879

Souza CN, Gasparino EC (2014) Pollen morphology of Fridericia Mart. (Bignoniaceae) from Brazilian forest fragments. Braz $\mathrm{J}$ Bot 37:83-94

Turner IM (1996) Species loss in fragments of tropical rain forest: a review of the evidence. J Appl Ecol 33:200-209

Vieira S (1981) Introdução à Bioestatística. Campus, Rio de Janeiro

Zar JH (1996) Biostatistical analysis, 2th edn. Prentice Hall, New Jersey 